\title{
THE STUDY AND DESIGN OF A NATIONAL SUPPLY CHAIN FOR THE AEROSPACE TITANIUM COMPONENTS MANUFACTURING INDUSTRY
}

\author{
LENE VAN DER MERWE1 \\ GEORGE RUTHVEN* \\ KONRAD VON LEIPZIG** \\ *gar@sun.ac.za \\ **kvl@sun.ac.za \\ Department of Industrial Engineering, \\ University of Stellenbosch, South Africa
}

\begin{abstract}
Titanium's strength-to-density ratio, corrosion resistance and high thermal compatibility makes it the perfect metal for aerospace. Titanium is for instance used for the structural airframe, seat tracks, engine components and landing gear of aircraft. The Boeing 787 that had its test flight in 2009 is one of the latest aircraft designs that incorporates a substantially higher percentage of parts manufactured from titanium due to the weight benefit.
\end{abstract}

Titanium's extensive use in aerospace applications ensures that the aerospace market is the main driver of titanium metal demand. South Africa is the second largest titanium producer in the world after Australia. The abundance of titanium in South Africa together with the growing demand has led it to be identified as a beneficiation priority in a collaborative government initiative, called Titanium Beneficiation Initiative (TBI).

The purpose of this paper is to develop a supply chain model for the anticipated South African titanium component manufacturing industry.

\section{INTRODUCTION}

Titanium, also known as the 'space age' metal because of its useful properties, is used in a wide array of markets that includes aerospace, defence, energy, medical and sporting equipment. Although titanium is an expensive material to produce, technology improvements and the advantages of its unique properties have contributed to the rise in the demand for titanium globally. The abundance of titanium in South Africa together with the growing demand has led it to be identified as beneficiation priority in a collaborative government initiative, called Titanium Beneficiation Initiative (TBI) (Department of Trade and Industry [DTI], 2005).

\footnotetext{
${ }^{1}$ The author was enrolled for her BEng degree at the Dept. of Industrial Engineering, University of Stellenbosch.
} 
Although there are a few engineering companies in South Africa sporadically manufacturing components for the aerospace, medical and research industry from imported solid titanium, there is no established, continuous and sustainable industry for titanium components. The purpose of this paper is to develop a supply chain model for a future South African titanium component manufacturing industry. The methodology followed starts with an examination of the history and properties of titanium, as well as a description of the titanium mineral processing steps. A discussion of the sources of supply both globally and locally follows. The aerospace industry's importance in the titanium supply chain, with specific reference to Boeing 787's involvement, is highlighted. The important and active titanium supply chains in the world, including specific role players, are analysed. Finally, a supply chain will be developed regarding a proposed solution for the South African titanium metal industry. As aerospace is the largest single consumer of titanium metal applications, the analysis and the design and development for a South African titanium supply chain will focus on the metal's application in the aerospace industry. Possible key partners and/or role players are identified, and their importance in the supply chain illustrated. This should provide people in positions of authority with the tools to make decisions regarding the further development of or participation in the South African titanium industry.

\section{HISTORY AND PROPERTIES OF TITANIUM}

\section{History}

Titanium was first discovered as a magnetic black sand near beaches of Cornwall, England, by Reverend William Gregor, an amateur mineralogist in 1791. A few years later a German chemist, Martin Heinrich Klaproth, separated titanium dioxide $\left(\mathrm{TiO}_{2}\right)$ from the mineral rutile (one of the five forms of titanium dioxide found in nature) and named the new element titanium after the Giants from Greek mythology (the Titans) (Mbendi, 2010). In 1825 a Swedish chemist, J.J. Berzelius, performed a crude recovery of titanium metal and in 1910 M.A. Hunter developed the Hunter process that recovered pure metallic titanium (99.9\%) (Comstock, 1955). Although titanium metal could be separated from the minerals in which they occur since 1825 it was only used outside of the laboratory after 1938 when William Justin Kroll proved that titanium could be reduced from titanium tetrachloride $\left(\mathrm{TiCl}_{4}\right)$ and patented his method as the Kroll process.

\section{Titanium's properties}

'Titanium is the ninth most abundant element in the earth's crust and is the fourth most abundant structural metal after aluminium, iron and magnesium. Currently titanium is mostly consumed as titanium dioxide not as a metal but rather as a white pigment used in paint, paper and plastic' (VSMPO, 2009: 4). One of the most beneficial properties of Titanium metal is its high strength-to-weight ratio. Titanium is as strong as steel but is $45 \%$ lighter. Titanium can be alloyed with iron, aluminium, vanadium, molybdenum, among 
other elements, to produce strong lightweight alloys, with titanium alloys for instance up to twice as strong as aluminium alloys (Naik, 2010). It also possesses other useful properties such as a high resistance to corrosion; high melting temperature (with a melting point over $1660{ }^{\circ} \mathrm{C}$ and a boiling temperature of $3287{ }^{\circ} \mathrm{C}$ (Naik, 2010); it is fairly hard; and it is compatible with the human body (Mineral Information Institute [MII], 2010). Titanium is highly reactive at high temperatures and therefore has to be machined and cast in a vacuumed area. This increases titanium manufacturing costs which increases the price of titanium products even further (Treurnicht, 2010).

\section{Titanium mineral processing steps}

\section{Mining and beneficiation}

The first step of the titanium production cycle is the extraction of titanium ore through titanium mining. This usually takes place on the surface, with the economically exploitable deposits of titanium minerals being present in heavy mineral sand ore deposits, or in beach sand in which the titanium minerals were concentrated by natural erosion (Department of Science \& Technology [DST], 2008-2009). Pricing for these products ranges from as low as US\$50/t to over US\$600/t depending on grade and end-use application (Iluka Mineral Sands Overview, 2009).

\section{Smelting}

- Titanium ore to sponge

Rutile, synthetic rutile and titanium slag must be converted into $\mathrm{TiCl}_{4}$ before it can be further processed into pure $\mathrm{TiO}_{2}$ or titanium metal by means of a choice of laborious processes. 'Only 5 percent of all mined and synthetic titanium minerals are actually used to make titanium metal, with the remaining 95 percent used to manufacture titanium dioxide powder' (Hogan, Mcginn \& Kendall, 2008). The second process is however of interest to the topic under discussion. In this process the titanium concentrates are subjected to a complex, multi-stage, batch conversion process. The titanium ores are chlorinated to produce titanium tetrachloride and then reduced with magnesium (called the Kroll process) or sodium (called the Hunter process) to form commercially pure sponge, a porous metal, and magnesium chloride as a by-product.

\section{- Producing ingots from sponge}

Titanium ingot is produced from melting titanium sponge, titanium scrap, or a combination of both in an electric arc furnace. Titanium ingot is often an alloy, containing such metals as vanadium, aluminium, molybdenum, tin, and zirconium. Titanium alloyed with $6 \%$ aluminium and $4 \%$ vanadium, $\mathrm{Ti}-6 \mathrm{Al}-4 \mathrm{~V}$, is most commonly used in the aerospace industry. 


\section{Primary and secondary fabrication: manufacturing and production}

Titanium ingots or slabs undergo primary fabrication processes, such as hot rolling and forging in order to produce semi-finished products, referred to as titanium mill products, such as plate, sheet (which can be cut into strips and then formed into tubes or pipes), bar, rod and wire (Titanium Industries, 2010). Production of finished titanium products such as parts and components from generic mill products requires a variety of secondary fabrication processes, such as forging, extrusion, hot forming, machining and casting. Secondary fabrication of titanium is similar to that for other metals, except for titanium's toughness and reactivity that slows the machining process and quickly wears out tools. It is capital- and energy-intensive, requires multi-step, high temperature batch processes and cannot be exposed to the atmosphere because its great affinity for oxygen, nitrogen, carbon, and hydrogen will make the metal brittle. 'Therefore, either vacuum or inert gas metallurgy techniques are necessary to reduce and process the metal. In addition, the hardness of the metal makes the machining process more difficult and time consuming. Also, machining generates large amounts of scrap, and the high price of titanium makes this waste a significant expense' (Titanium Industries, 2010).

\section{Scrap}

'Titanium secondary fabrication is the primary producer of titanium scrap that is fuelling the titanium recycling sector. Although the melting of titanium scrap poses some additional challenges, the sheer value of the metal, combined with the large quantities that are discarded in the fabrication process, is making it economically viable. The current evaluation of the titanium market is estimated at around two billion dollars worldwide' (Titanium Industries, 2010).

\section{Global interest in titanium metal}

Titanium metal is used in a wide variety of markets that includes aerospace, defence, energy, medical and sporting equipment. Titanium is known as the 'space age' metal because of its useful properties. These properties make titanium a very desirable metal for the critical and demanding aerospace, industrial and chemical industries (Halflich, 2010; Metalnewsnet [MNN], 2010). Projections of up to $40 \%$ growth for titanium products for the next few years have been made by the Titanium Market Report (2012). This is mostly attributed to the aerospace industry, using more than $50 \%$ of the available metal, for newer, more fuel-efficient aircraft.

\section{GLOBAL TITANIUM METAL SUPPLY CHAIN}

There are a number of key companies that are recognised as the global leaders within the industry. Their information will be used as a benchmark for the South African titanium industry to determine what is needed to develop a supply chain (SC) and to compete in the industry. In Figure 1 the process flow of activities with the participating companies included in this paper can be seen. 
The Study and Design of a National Supply Chain for the

Aerospace Titanium Components Manufacturing Industry

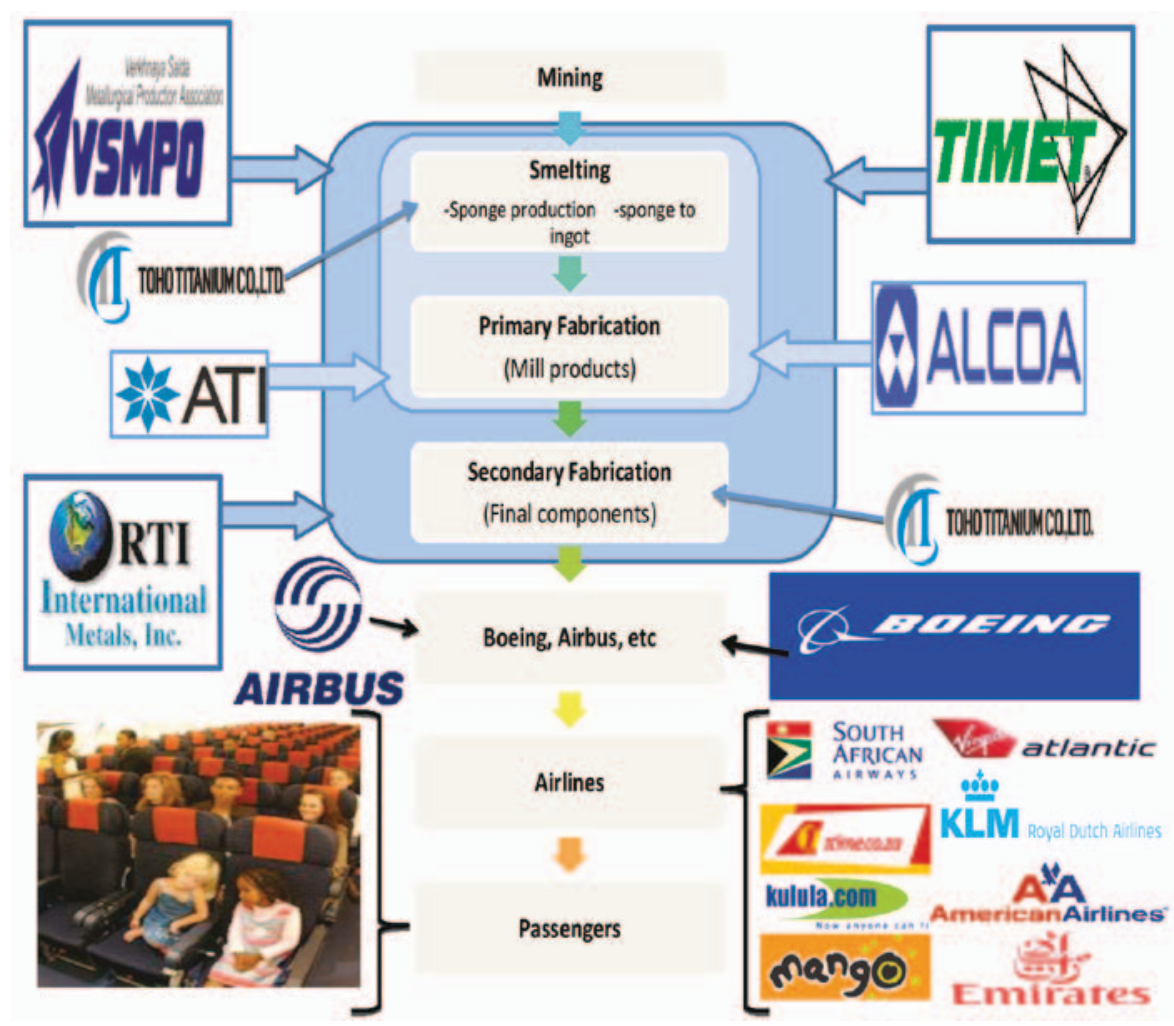

Figure 1: Global commercial aircraft titanium process flow with participating companies - from raw material to end user

Three of the major integrated companies, (as per www.titaniumexposed.com) namely VSMPO-AVISMA (Verkhnaya Salda Metallurgical Production Association - Russia), TIMET (Titanium Metals Corporation - USA) and RTI (International Metals - USA) supply chains were analysed in this section of the study. They were then integrated to obtain an understanding of the global supply chain. These can be seen in Figures 2 to 5.

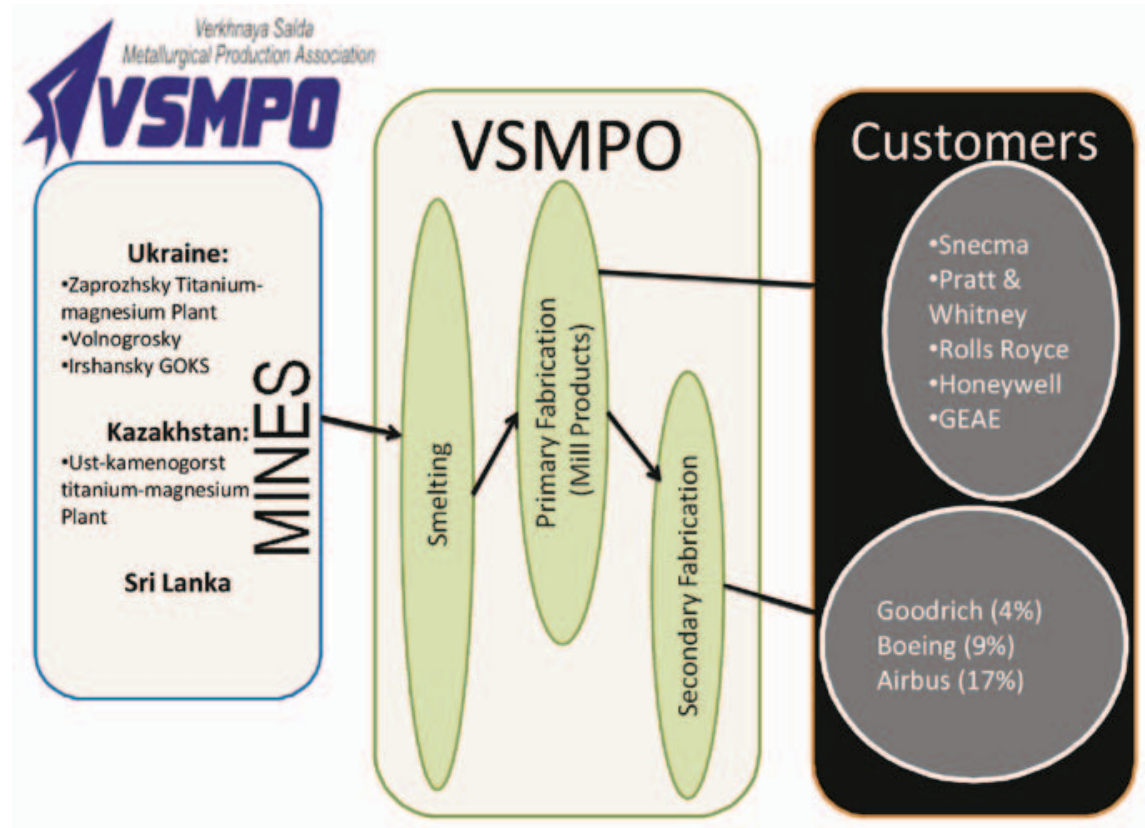

Figure 2: VSMPO's supply chain 


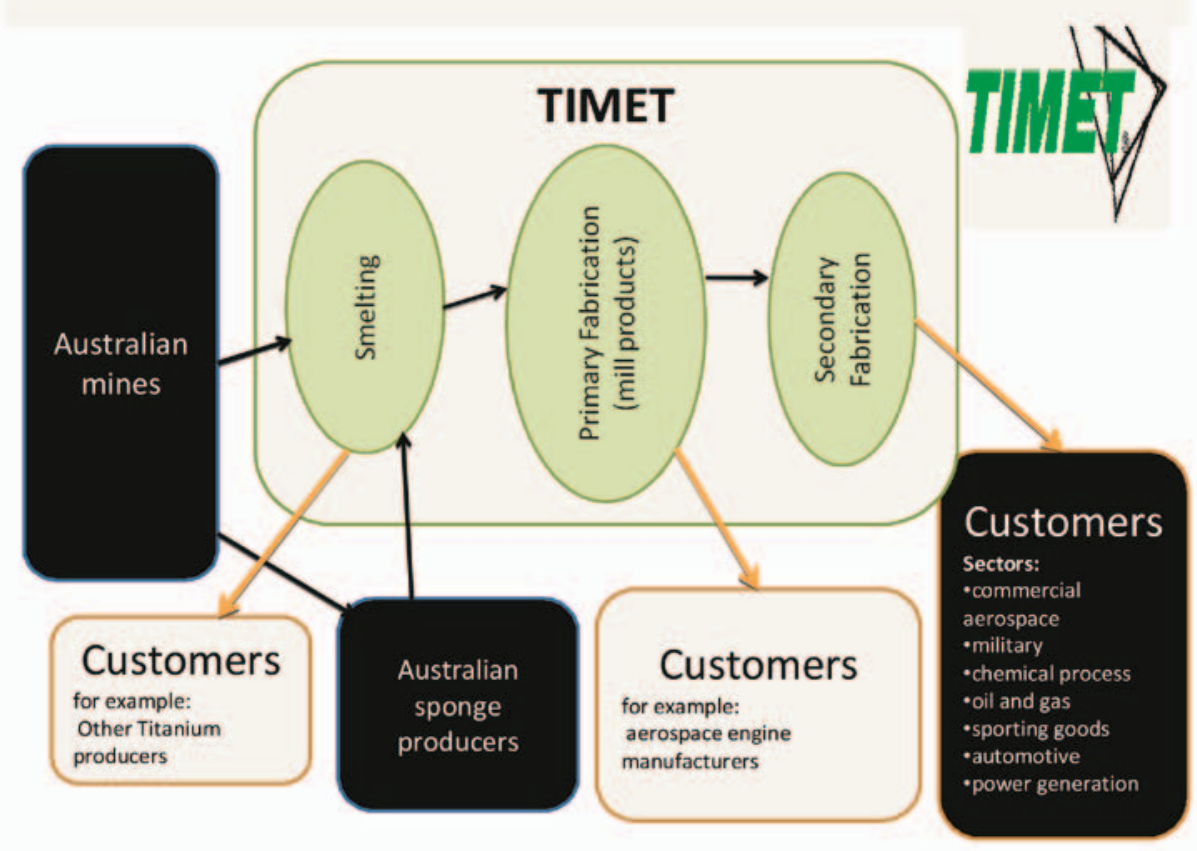

Figure 3: TIMET's supply chain with plants located in South Africa and China

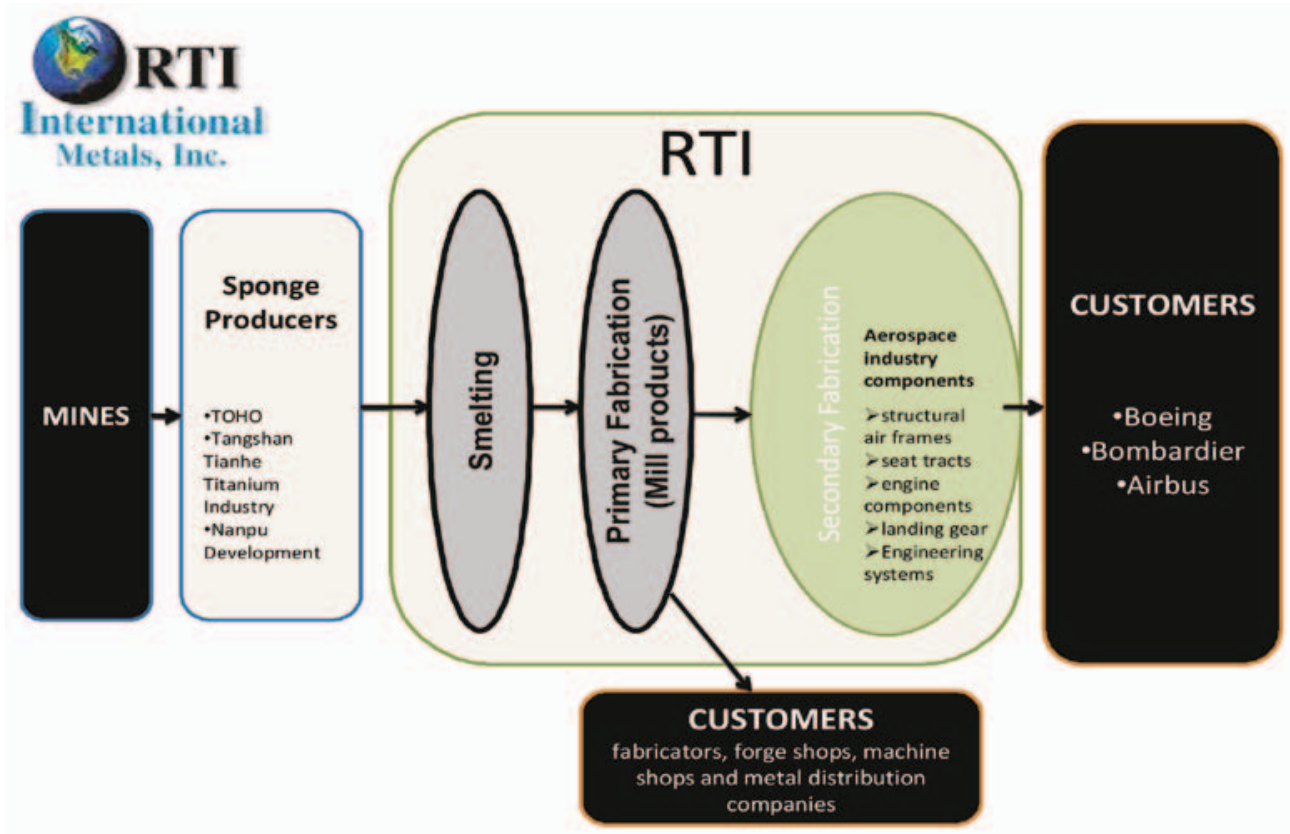

Figure 4: RTI's supply chain

From the three companies above, the links, representing the typical SC components physical, information, financial or knowledge flow - were shown in a simplified state. These relatively uncomplicated supply chains were analysed separately and were then integrated to obtain an understanding of the global supply chain. Once attention is drawn to the linkages in Figure 5, it can be seen that even the slightest increase in the quantity of the links (or transactions) will have a multiplication effect on the increase in complexity. Therefore 
the illustrations used throughout for the various supply chains only show the major links between supply and demand. The more traditional supply chain designs couple the multiple and detailed supplier, manufacturer, distributor, wholesaler, retailer and customers to show the order of complexity prevalent per industry. The proposed South African supply chain will also follow the above simplified configuration but in no means does it imply that it will escape the complexities of an established supply chain.

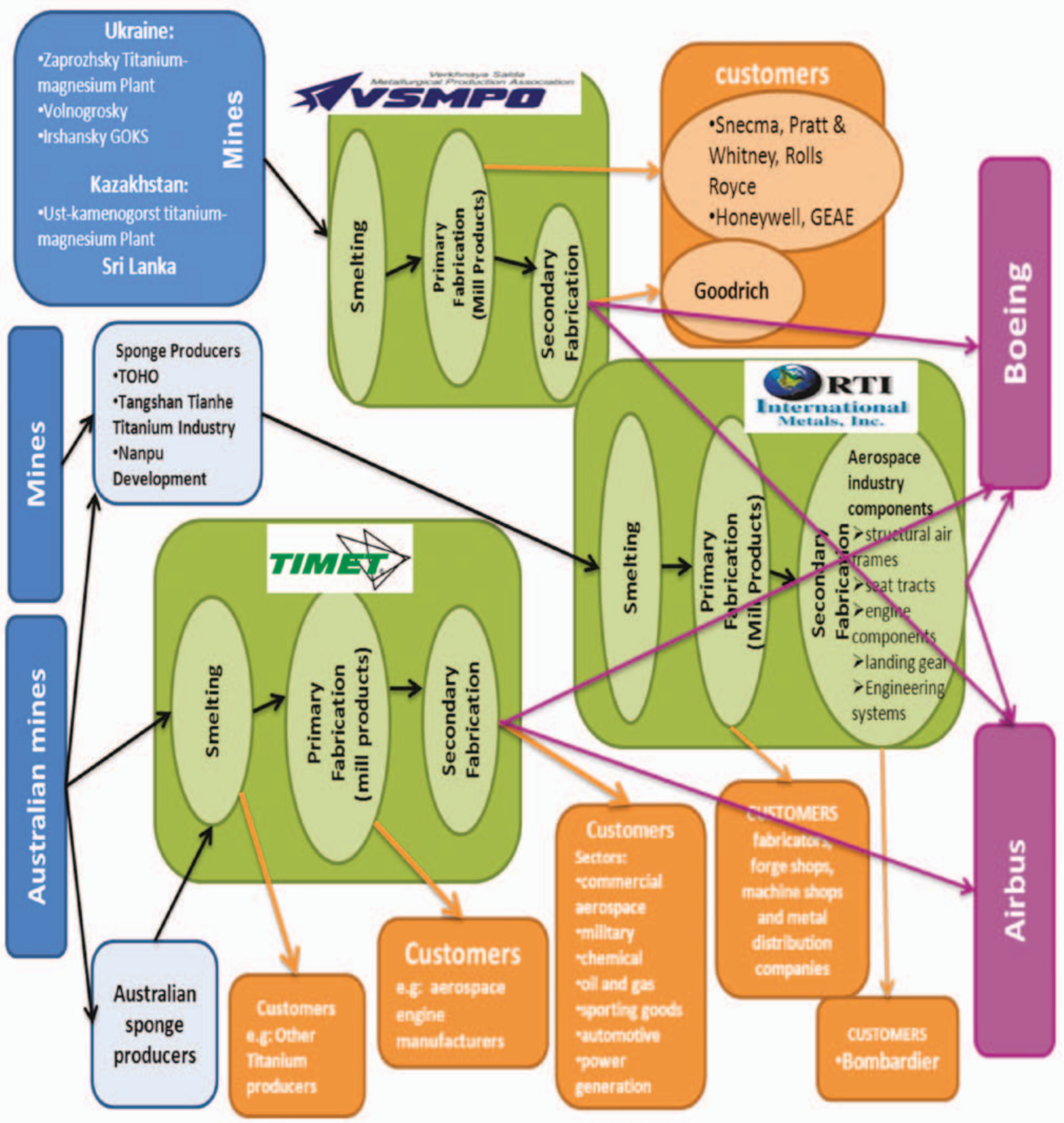

Figure 5: Integrated supply chain showing the increase in complexity of the global market versus the previous localised supply chains 


\section{Mines}

This section shows the widespread variety of titanium producers that form part of the global supply chain. Upgraded ilmenite supplies about $90 \%$ of the world's demand for titanium minerals (lluka Mineral Sands Overview, 2009). The world's largest open-cast ilmenite mine is the Tellnes mine located in Sokndal, Norway. Other open-cast mines are located at Karhujupukka, Kolari, in northern Finland, and the Balla Balla magnetite-irontitanium-vanadium ore deposit in the Pilbara of Western Australia (Moskalyk \& Alfantazi, 2003). Major mineral sand mining operations are situated at Richards Bay Minerals in South Africa; Coburn, WIM 50, Douglas, Pooncarrie, Murray Basin, Eneabba in Australia; Indian Rare Earths (IRE) in India; and QIT Madagascar Minerals (Chadwick, 1995). The research concentrated mainly on lluka Mining in Australia (because of Australia's global prominence); Kenmare's Moma Mine in Mozambique (as a relatively new mine in a neighbouring country); and mining in the Commonwealth of Independent States (CIS), formerly the Soviet Union (these operations function under financial and other constraints that are very similar to the South African experience) (Sakwa \& Webber, 1999).

\section{Australian titanium mines}

Australian mineral sands deposits occur as recent beach deposits as well as ancient beach deposits located inland. Most deposits are located along the west coast, north and south of Perth. Australia is a leading producer of ilmenite, rutile and zircon (Mbendi, 2010).

\section{Titanium ore-producing mines in the CIS}

The Commonwealth of Independent States (CIS) is a regional organisation whose participating countries are former Soviet Republics, formed during the break-up of the Soviet Union (Sakwa \& Webber, 1999). The two largest producers of titanium resources in the CIS are the Ukrainian enterprises Volnogorsk State Mining and Metallurgical Plant in the Ukraine (VSMMP) and Irshansky GOK. 'Titanium bearing ores are also mined by JSC Sevredmet in Murmansk Oblast, Russia. Petrochemical company JSC Yaregskaya, based in Komi Republic, Russia, produces a small volume (up to 1000 tpa $\mathrm{TiO}_{2}$ ) of leucoxene concentrate, but plans to increase production to 30000 tpa of $\mathrm{TiO}_{2}^{\prime}$ ( $\mathrm{CIS}$ Titanium resources, 2003).

\section{Smelting}

There are only a limited number of companies that produce either sponge or ingot (Somi, Younossi, Goldsmith \& Michael, 2009). 'Of the sponge producers, Russia's VSMPO-AVISMA is the world's largest producer of high-quality aerospace titanium. In the U.S., the main highquality aerospace titanium producer is TIMET. In the industrial sector, the market, in addition to being served by TIMET, is also served by the Japanese ingot producers RTI International Metals, Inc. and UNITI - a joint venture between VSMPO and ATI' (Vulcan, 2010).

\section{Primary and secondary fabrication: mill products}

Titanium mill products, such as plate, sheet, billet and bar, are produced from titanium ingot or slab through such primary fabrication processes as rolling and forging. 


\section{Distributors}

\section{ETS}

European Titanium Services (ETS-SEPT, 2010), among others, stocks, distributes and sells Titanium in all its forms although mostly semi-finished titanium products such as bars, sheets, wire, tubes, profile and flat sections. (ETS-SEPT, 2010; Johnston, 2010).

\section{THE AEROSPACE INDUSTRY}

Aircraft operations place exceptional stress on material and parts and the material used for this purpose has to be light, should have high specific strength, be resistant to heat, fatigue, cracks and corrosion (Somi, Younossi, Goldsmith \& Michael, 2009). Titanium and its alloys meet these requirements and are therefore an attractive choice for many components in the aerospace industry.

\section{Aerospace industry dynamics}

To understand the motivation behind Boeing's supply chain it is important to understand the industry's dynamics and requirements. The most prevalent dynamic is the growing demand for air travel which invariably results in the need to expand existing fleets and to replace older aeroplanes with newer, more economical ones. It was envisaged that this would create a market for 27210 new aeroplanes worth $\$ 2.6$ trillion to be delivered over the next 20 years (Horng, 2004). To meet these demands the aerospace industry launched new initiatives to foster collaboration among suppliers and manufacturers in product development and production. Justin Hale, deputy chief mechanic explained the use and justification of new materials as follows:

The new approach offers weight savings on average of $20 \%$ compared to more conventional aluminium designs. The expanded use of composites, especially in the highly tension-loaded environment of the fuselage, greatly reduces maintenance due to fatigue when compared with an aluminium structure. This type of analysis has resulted in an increased use of titanium as well. Where loading indicates metal is a preferred material system but environmental considerations indicate aluminium is a poor choice, titanium is an excellent low-maintenance design solution. Titanium can withstand comparable loads better than aluminium, has minimal fatigue concerns, and is highly resistant to corrosion. Titanium use has been expanded on the 787 to roughly $14 \%$ of the total airframe. With the expanded use of composites and titanium combined with greater discipline in usage of aluminium, Boeing expects the 787 to have much lower non-routine labour costs than a more conventional metallic airframe (Hale, 2006).

\section{Boeing's 787 supply chain model}

Boeing's new supply chain model used in the 787 Dreamliner represents a significant break with past practices in the aerospace industry, allowing major partnering and suppliers 
playing an unprecedented role in terms of design, development, production and aftermarket support. It is clear that Boeing adopted most of the important principles of lean supply chain management (value-adding processes reducing waste) emulated by Europe and North America namely: 'establishing collaborative relationships with suppliers, delegating more design and manufacturing responsibilities to suppliers, integrating suppliers early into a product development stage and developing a knowledge-transfer network among suppliers' (Horng, 2004). The lean concept manifests itself by reducing the 'distance' to Tier 1 as well as 2 and 3 . This enables a closer relationship with the tier levels as compared to the traditional supply chain where Tiers 2 and 3 play a lesser role. In Figure 6 our interpretation of the supply structure of a lean supply chain and specifically the Boeing 787 supply chain is illustrated in a somewhat unconventional format. It serves as an alternative approach to the more conventional illustration of a drawn-out parallel and sequentially linked supply chain.

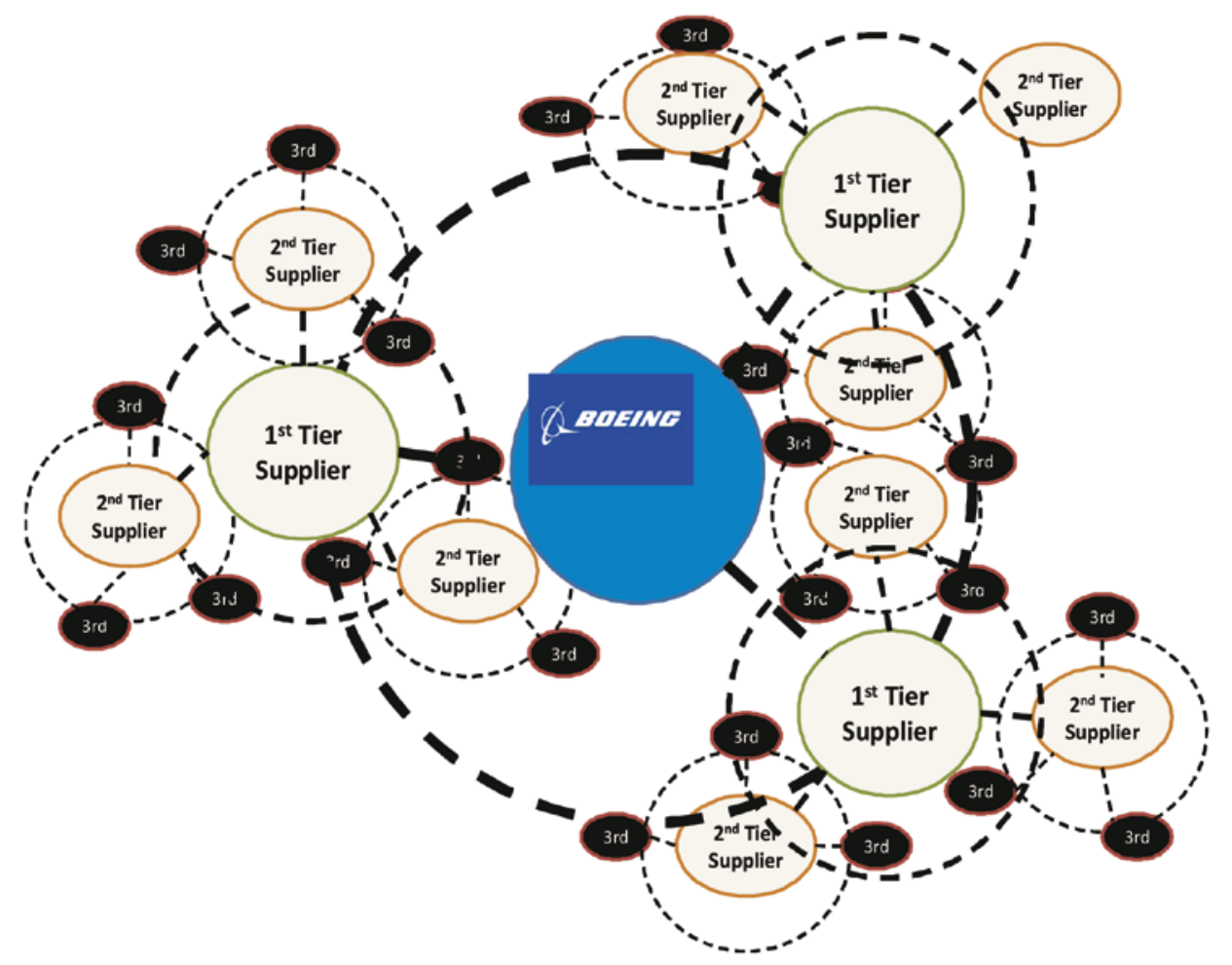

Figure 6: An unconventional illustration of a supply chain by interpreting Boeing's 787 approach

There is a further lean aspect developed by James Ayers in his Handbook of Supply Chain Management that supports Boeing's approach and should be included in the operations of a local supply chain. It is the two complementary concepts of a 'flexible workforce and with creative thinking that encourages workers' ideas for improving operations'.

\section{Boeing supplier relationships}

Boeing views their relationship with their suppliers as key to their agility, integrity, competitiveness and ability to meet customers' demands and they therefore go to great 
lengths to cultivate a healthy and functional relationship. They view themselves and their suppliers as one team with one future (Boeing, 2010). Steven K. Schaffer, vice president of Boeing Commercial Airplanes' Global Partners is responsible for the daily management of more than 1200 suppliers supporting the manufacture and service of Boeing commercial aircraft, including the 787 Dreamliner. However, Boeing's biggest problem with the production of the Boeing 787 Dreamliner was and is the colossal delays due to subcontractor problems (Greising \& Johnsson, 2007).

\section{Boeing's contribution to SA business}

Boeing's policy to create worldwide partnerships with customers has led them to invest in South Africa (D'Angelo, 2008). Boeing has formed partnerships with South African companies like South African Airways, Denel and Aerosud as well as with the South African government. They expanded the manufacturing facilities and provided training at Denel and Aerosud, South Africa's two largest aerospace companies where parts for various Boeing models are being manufactured (Boeing's Contribution to South African Business, 2005). Boeing's research and development organisation, Phantom Works, implemented research projects in conjunction with the Council for Scientific and Industrial Research (CSIR). Boeing Phantom Works and the University of Stellenbosch have signed a number of specific research project agreements on the making and manufacturing of aircraft components and spare parts. Through this interaction, South African scientists and engineers are also exposed to international best practices and new technologies (D'Angelo, 2008).

\section{A SOUTH AFRICAN TITANIUM SUPPLY CHAIN DESIGN}

\section{Main producers}

South Africa is the second largest titanium mineral producer in the world after Australia. Three major mines are responsible for the recovery of titanium in South Africa, namely Richards Bay Minerals, Exxaro's Hillendale and Namakwa Sands mines (Motsie, 2008).

\section{Richards Bay Minerals}

Richards Bay Minerals (RBM) is the single largest producer of titanium products in the world. The minerals extracted in the mining process end up as high quality pig iron (used in vehicle manufacture); titania slag (a basic pigment used in paints); rutile sand (used as a flux for welding, in the production of steel and as a high quality pigment in paints, plastics, rubber and textiles); and zircon (used in the production of ceramic products, steel, glass and even a number of anti-perspirants) (Richards Bay Minerals, 2010).

\section{Exxaro}

Exxaro Sands currently comprises KZN and Namakwa Sands, which houses the South African operations, and Australia Sands, which houses the Australian operations (Exxaro, 2009). 


\section{KwaZulu-Natal Sands}

KwaZulu-Natal Sands (KZN Sands), a subsidiary of the international mining giant Exxaro, encompasses the mining, refining and smelting of mineral sands to produce titanium slag, the company's main product (Exxaro, 2009).

\section{Namakwa Sands}

Namakwa Sands, another Exxaro subsidiary, undertakes the mining and beneficiation of heavy minerals. The recovered products are transported by rail to the smelter based close to Saldanha Bay, $150 \mathrm{~km}$ from Cape Town, where two furnaces are operated to smelt ilmenite and to produce titanium slag and pig iron (Exxaro, 2009).

\section{Markets and future developments}

Collectively, Exxaro's mineral sands operations produced 272 kt of slag, 193 kt of zircon, $113 \mathrm{kt}$ of synthetic rutile and $43 \mathrm{kt}$ of pigment in 2008 (Exxaro, 2009).

\section{Beneficiation initiatives and research projects}

None of the titanium slag and rutile produced in South Africa can currently be used to manufacture titanium metal and are mainly used in the pigment industry as a result of the low purity of the processed mineral sands. The South African titanium metal supply chain currently only consists of a knowledge supply chain. There are many institutions gathering knowledge and know-how and producing mostly experimental or prototype products. The raw to hard materials, fabrication and distribution of titanium product does not yet exist. A depiction of the Knowledge Supply Chain can be seen in Figure 7 (excluding companies working in the armaments industry).

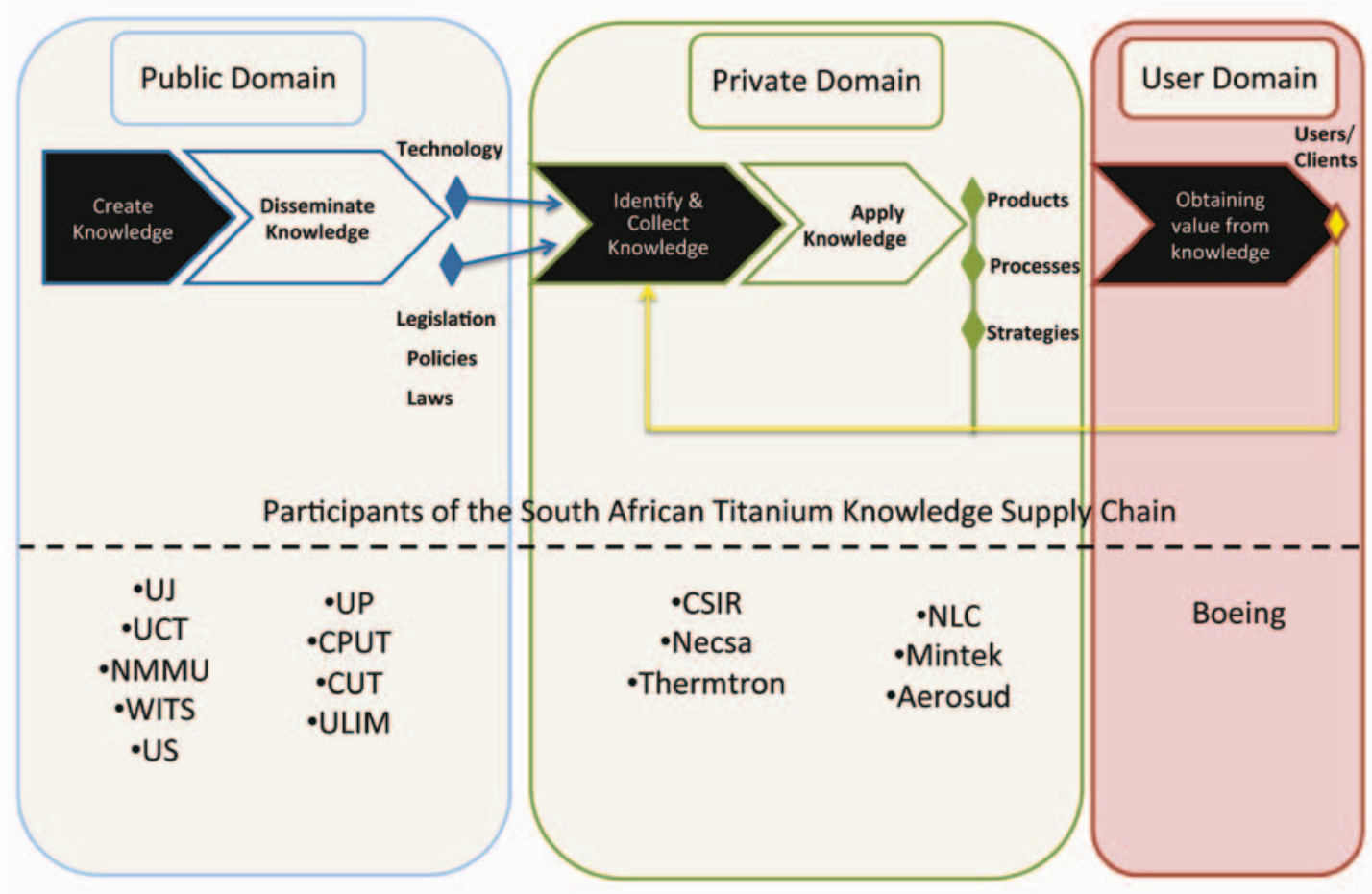

Figure 7: South Africa's knowledge supply chain 
The South African government (Departments of Trade and Industry [DTI] and Science and Technology [DST]) has recently indicated that it considers titanium a mineral resource with the potential to serve as a strategic economic driver for the country if a local processing and production industry could be successfully established (DST Annual Report, 2008-2009).

\section{DTI and DST}

Titanium has been identified as a beneficiation priority in a collaborative initiative for the Chemical Sector, called Titanium Beneficiation Initiative (DTI, 2005). One of the main strategies is the improvement of South Africa's beneficiation competencies in order to prevent the weakening of long-term revenues. The department (DST), through the resourcebased industries unit, has supported titanium metal research and development through the Light Metals Development Network (LMDN) of the Advanced Metals Initiative since 2006 (DST Annual Report, 2008-2009). The aerospace sector is the key target market in the development of a titanium industry in South Africa (DTI, 2005). On the manufacturing side the government's DST established an Advanced Manufacturing Technology Strategy (AMTS) in 2003, aimed at developing competencies in order to strengthen the technological base and competitiveness of the South African manufacturing sector (DST Annual Report, 2008-2009).

Lessons may be learnt from the Chinese government's support for their metals and rare earth elements industries which is area specific; it includes levers/incentives such as 'low/ free land use rights (from local government); VAT refunds or waiver (funded both by central government and local government); wholly government funded projects (funded both by central and/or local government); duty and VAT exemption for imported capital equipment; tax incentives for exports; interest free or interest subsidized loans as well as recommendations to the World Bank or to foreign governments for funding' (Bluepeter Management Consulting and Access Market International [Pty] Ltd, 2004).

\section{CSIR}

Although South Africa does not have any facilities that commercially manufacture titanium mill products or titanium components for commercial aerospace production, the CSIR has a state-of-the-art investment casting facility that is exclusively used for research in developing capabilities in casting of titanium alloys (thin-walled structures).

\section{Aerospace advanced production}

'In 2008 an aircraft subcomponent was successfully produced to the technical specifications of one of the world's leading aircraft manufacturers by the DST-funded research team using investment casting technology' (DST Annual Report, 2008-2009). At present South Africa is not in a position to design and manufacture an entire, fully integrated aircraft system and the emphasis has therefore been placed on developing key competencies where 
South African companies can become part of the global supply chain of the major first- and second-tier aerospace companies like Boeing, Airbus, Embraer, Rolls-Royce and Snecma. The Centurion-based Aerosud is an accredited supplier to Boeing, Airbus and BAE systems. According to Aerosud's marketing manager, Derek Dollman, the firm is already doing development work with titanium but not yet selling any parts (D'Angelo, 2008).

\section{Research and technology participants}

Research and design capabilities exist at tertiary institutions, the CSIR and at private companies (large and small).

Some of the research areas and partners include the following:

(a) Boeing is participating in various titanium research projects at a number of South African universities, including the University of Stellenbosch's Faculty of Engineering where research has been undertaken on efficient machining of titanium mill products, in conjunction with the Universities of Johannesburg, Cape Town and Germany's Fraunhofer Institute in Chemnitz (Hogan, Mcginn \& Kendall, 2008; Hanekom, 2009; Treurnicht, 2010).

(b) Most of the emerging alternative methods centre around the production of titanium metal powder as the main product. The powder can then be used in the existing powder metallurgy (PM) industry as an alternative method for the fabrication of components. Engineering News of 1 July 2011 reported that the CSIR's two-year-old Titanium Centre of Competence is in a close global race to commercialise a more cost-effective method of producing titanium metal. As the Kroll process involves expensive processes, Dr Du Preez believes the CSIR's new method uses better technology than found in the US and produces dense metal parts. This could support the establishment of a titanium industry by 2020 (Du Preez, 2011). The powder is also used for additive manufacturing - Aerosud and various other entities are currently doing research in this field especially in direct metal laser-sintering (DMLS). DMLS is an emerging technology for additive manufacturing of metal parts and it is very well suited for the production of high-strength, low-weight components at low manufacturing volumes (Wohlers, 2002). According to Marius Vermeulen at Aerosud they are involved in research of machines for handling larger components than currently available (Vermeulen, 2010).

\section{A proposed titanium supply chain for South Africa}

South Africa's current lack of a comprehensive titanium supply chain for the aerospace industry offers the opportunity to design a formal supply chain from inception. As with any other, it will need to be managed and improved upon as the supply chain grows into a mature industry. Valuable lessons can be learnt by taking into consideration the global titanium supply chain together with the aerospace industry dynamics, needs and regulations, and Boeing's supply chain. This will assist in determining the elements of a competitive South 
African supply chain. The establishment of a local titanium industry will result in enterprise development across all the tiers of the industry over time (Van Tonder, 2009).

\section{New production methods}

The current technology used in the process of producing titanium products is almost 100 years old. New technology is necessary to drastically reduce the cost of production of titanium metal. The next step in the 'old' value chain is the production of titanium sponge. It will be more advantageous to design a supply chain around the new technologies being researched by the various institutes and universities. The new technologies mostly rely on the production of titanium powder instead of titanium solids. By using a new and upcoming technology like powder metallurgy, South Africa can ensure a reduced and less complex supply chain with improved logistics and communication flow. The new technology impacts on the cost and quality of the products produced and will result in a competitive advantage. A proposed supply chain model for the above-mentioned scenario using existing South African companies and indicating the areas of opportunity for new companies can be seen in Figure 8.

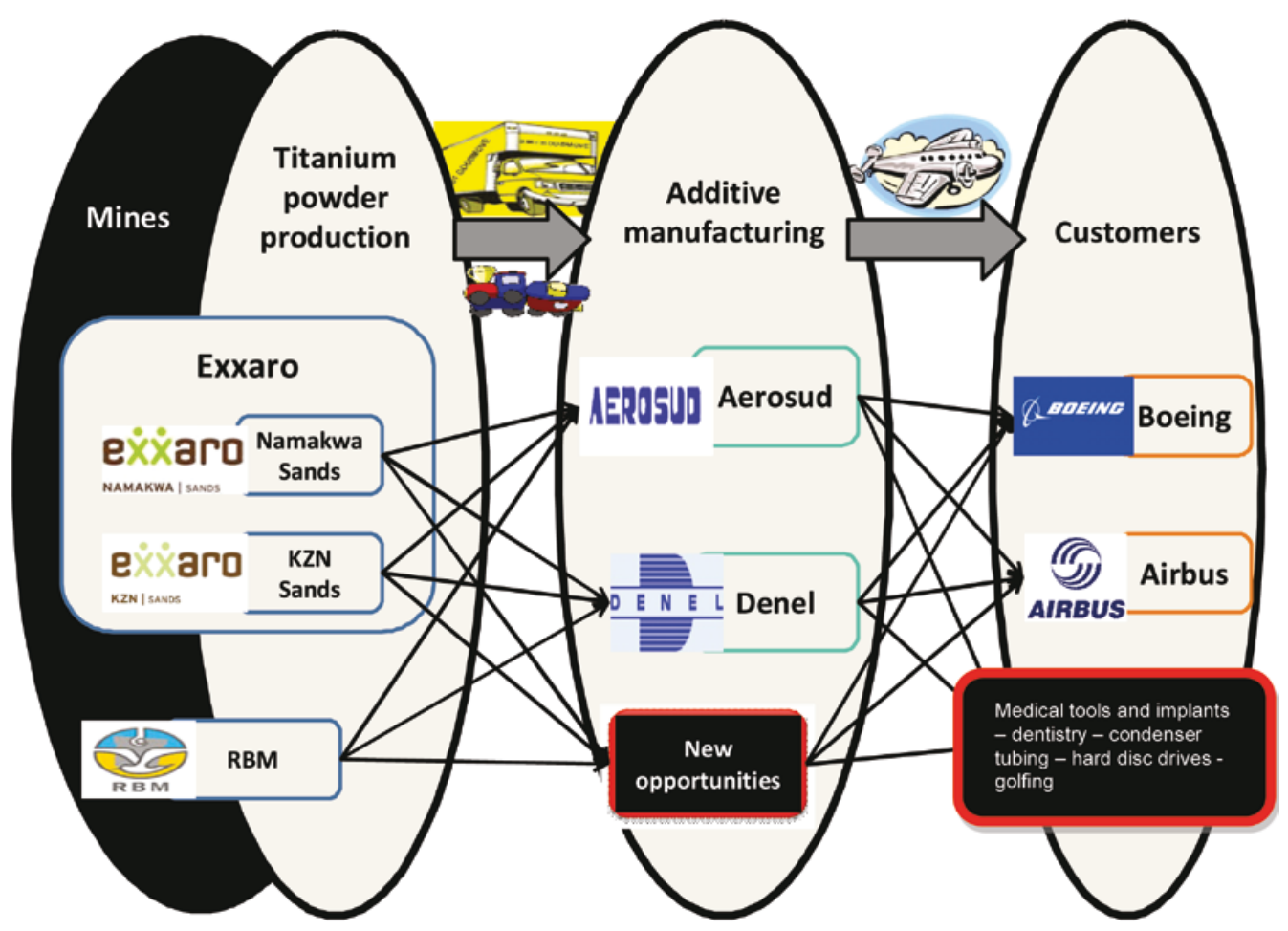

Figure 8: Proposed South African titanium supply chain

The proposed model is a conventional and simplified supply chain. The raw material sources and the possible companies to process their product are identified. As the aerospace markets are well documented, only the large aeroplane customers are shown. The article and the supply chain points the way for the authorities and industry to establish and manage first the proposed and uncomplicated supply chain with the existing participants. Establishing 
new companies with little known experience in the field should be done at a later stage. The authors firmly believe that the cost of R\&D for 'new high-risk opportunities' should be curtailed until such time as the supply chain has been established as illustrated, mainly developed around known entities. Similar to the Boeing illustration and their systems, the known and established players in the South African field should be seen as the dominant tier in the market and they will need to establish and arrange the second and third tiers as per the Boeing model. The benefit of a supply chain approach lies with developing, supporting and maintaining the linkages shown. The linkages also clearly illustrate that although governmental support will favour a few companies in the beginning, we assume, due to the unique technologies involved, that the likelihood of monopolies forming is remote. The linkages and complexities will increase as the second and third tiers are established. The case has also been made for the support offered by Boeing such as technology transfers.

\section{Lean manufacturing methods}

To ensure that this supply chain will be able to compete globally it may be beneficial for all the participating companies and mines to practise lean manufacturing methods as applied and portrayed by Boeing in the previous section. Such lean manufacturing methods in the supply chain context could include the engagement of the people doing the work and/or being extremely efficient in reducing waste as proposed by James Ayers (see Boeing's 787 supply chain model above).

\section{CONCLUSION}

The establishment of a new and lean titanium metal supply chain is possible and has the potential to benefit the country, especially in wealth and job creation, but it faces a series of sturdy hurdles. It will require sustained research investment, significant technological developments and creative facilitation by all role players, including government. Notwithstanding the hurdles, the authors believe there is a huge opportunity (projected growth of $40 \%$ over the next few years) available to be tapped by South African entrepreneurs and government alike in establishing a leading edge titanium industry once the additive technologies have been mastered and a viable and lean supply chain has been developed. Therefore this paper supports Van Tonder's view that establishing a local titanium industry will result in enterprise development across all tiers of the industry over time (Van Tonder, 2009). 


\section{REFERENCES}

Ayers, J.B. 2006. Handbook of Supply Chain Management. New York. Auerbach Publications.

Bluepeter Management Consulting and Access Market International (Pty) Ltd. 2004. DTI Benchmarking of TechnologyTrends and Technology Developments.

Boeing. 2010. Boeing Suppliers. Retrieved April 12, 2010, from Boeing website: http:// www.boeing.com

Boeing's Contribution to South African Business. 2005, January 14. Engineering News.

Chadwick, J. 1995. SA mining international. Mining Magazine. May 1995, pS59.

CIS Titanium resources. 2003. Retrieved April 28, 2010, from Info Mine Research Group: http://www.infomine.ru/pages/143

Comstock, G.F. 1955. Titanium in Iron and Steel. New York. John Wiley and Sons Inc.

D'Angelo, A. 2008. Boeing encourage local titanium All. Retrieved April 10, 2010, from Business Report On-line : http://www.busrep.co.za/index.php?fSectionld=566\&fArticle Id $=4674753$.

DST. 2008-2009. DST Annual Report. From Department of Science and Technology: http:// www.dst.gov.za/publications-policies/annual-reports/DST\%20Annual\%20Report\%200809.pdf

DTI. 2005, October 14. Department of Trade and Industry. Chemicals Sector Development Strategy, 26-30.

Du Preez, W. 2011. Titanium metal aspirations underpin SA's research push. 2011 July 01. Engineering News.

ETS-SEPT. 2010. Home: ETS-SEPT. Retrieved April 13, 2010, from sept-france: http://www. sept-france.com/GB/indexGB.html

Exxaro. 2009. Exxaro Annual Report. Retrieved May 10, 2010, from Exxaro: http://www. exxaro.com/conent/about/profil.asp

Greising, D. \& Johnsson, J. 2007, December 8. Behind Boeing's 787 delays. Retrieved March 22, 2012, from Chicago Tribune's website: http://www.chicagotribune.com/business/ chi-sat_boeing_1208dec08,1,4183069,full.story 
Hale J. 2006, Qtr 4. Boeing 787 From the ground up, Aeromagazine, www.boeing.com/ commercial/aeromagazine)

Halflich, F. 2010, February 4. Airbus advisory to RTI spurs titanium take-or-pay talks. American Metal Market (AMM).

Hanekom, D. 2009. Address by Deputy Minister Derek Hanekom. AMTS Annual Symposium. Midrand Conference Centre.

Hogan, L., Mcginn, E., \& Kendall, R. 2008. Research and development in titanium-implications for a titanium metal industry in Australia. Research Report for the Australian Bureau of Agricultural Resources and Economics. From Abar Economics: http://www.abareconomics. com/interactive/08-ResearchReports/Titanium/htm/chapter-3.htm

Horng, T.-C. 2004. A comparative analysis of supply chain management practices by Boeing and Airbus, long-term strategic implications.

Iluka Mineral Sands Overview. 2009. From Iluka website: http://www.iluka.com Iluka Mineral Sands Processing. (Accessed 2010).

Johnston, B. 2010, April 14. The role of ETS-SEPT in the titanium industry. (L. van der Merwe, interviewer)

Mbendi. 2010. Australia Titanium mining. Retrieved April 29, 2010, from Mbendi: http:// www.mbendi.com/indy/ming/hvym/au/au/p0005.htm

MII. (n.d.). Titanium. Retrieved April 04, 2010, from Mineral Information Institute: http:// www.mii.org.minerals/phototitan.html.

MNN. 2010, April 08. Titanium sponge price increased slightly. Retrieved April 14, 2010, from Metalnewsnet: http://www.metalnewsnet.com/Titanium/ZS16IPZ21o0n.html

MNN. 2010, April 09. Titanium Sponge prices may rise in the nearfuture. From Metalnewsnet: http://www.metalnewsnet.com/Titanium/vtl0191eunUa.html

Moskalyk, R.R., Alfantazi, A.M. 2003, July 16. Processing of vanadium: a review. Minerals Engineering.

Motsie, R. 2008. An Overview of South Africa's Titanium Mineral Concentrate Industry. Directorate: Mineral Economics, Department: Minerals and Energy (DME). 
Naik, A. 2010, February 11. Titanium Uses. Retrieved April 10, 2010, from Buzzle: http:// www.buzzle.com/articles/titanium-uses.html

Richards Bay Minerals. 2010. About RBM. Retrieved May 5, 2010, from Mbendi: http:// www.mbendi.com/orgs/cfq8.htm

Sakwa, R. \& Webber, M. 1999. The Commonwealth of Independent States, 1991-1998: Stagnation and Survival. Europe-Asia Studies Volume 51, Issue 3, 1999, 379-415.

Somi, S., Younossi, O., Goldsmith, B.W., \& Michael, T.L. 2009. Titanium Industrial Base, Price Trends and Technology Initiatives. Rand Corporation USA.

Titanium Industries. 2010. Titanium Industries one metal a thousand possibilities. http:// www.titaniumexposed.com/titanium-industries.html

Titanium Market Report. 2012. Aerospace titanium continues to fly. Retrieved March 21, 2012, from http://www.radical-departures.net/articles/titanium-market-report/

Treurnicht, N. 2010, March 26. (L. van der Merwe, interviewer)

Van Tonder, W. 2009, December. South African Titanium: Techno-economic evaluation of alternatives to the Kroll process. (D. Dimitrov, \& K. von Leipzig, Eds.).

Vermeulen, M. 2010, July 8. Electronic Engineer for Aerosud Aviation. (L. M. Van der Merwe, Interviewer)

VSMPO. 2009. VSMPO AVISMA. Retrieved April 2, 2010, from VSMPO web site: http:// www.vsmpo.ru/core.php?p=307

VSMPO-Avisma Titanium: Boeing Signs Deal with VSMPO-Avisma. (2008, January 02). Retrieved May 10, 2010, from Defense Industry Daily: http://www.defenseindustrydaily. com/titanium-boeing-signs-deal-with-vsmpoavisma-02528/

Vulcan, T. 2010, March 25. Titanium: Metal of the Gods. Retrieved May 5, 2010, from Open Forum: http://seekingalpha.com/article/194965-titanium-metal-of-the-gods

Wohlers, T. 2002. 'Wohlers Report 2002', Wohlers Associates, Fort Collins. 
Table of acronyms

\begin{tabular}{|l|l|}
\hline AMTS & Advanced Manufacturing Technology Strategy \\
\hline CIS & Commonwealth of Independent States \\
\hline CSIR & Council for Scientific and Industrial Research \\
\hline DME & Department of Minerals and Energy \\
\hline DMLS & Direct Metal Laser-Sintering \\
\hline DST & Department of and Science and Technology \\
\hline DTI & Department of Trade and Industry \\
\hline ETS & European Titanium Services \\
\hline IRE & Indian Rare Earths \\
\hline LMDN & Light Metals Development Network \\
\hline PM & Powder Metallurgy \\
\hline RBM & Richards Bay Minerals \\
\hline RTI & International Metals \\
\hline SC & Supply Chain \\
\hline TBI & Titanium Beneficiation Initiative \\
\hline TIMET & Titanium Metals Corporation \\
\hline VSMMP & Volnogorsk State Mining and Metallurgical Plant \\
\hline VSMPO & Verkhnaya Salda Metallurgical Production Association \\
\hline
\end{tabular}

